\title{
A BRIEF CONCEPT IN LANDSCAPE PHOTOGRAPHY
}

\author{
IWAN ZAHAR*
}

\begin{abstract}
Abstrak
Di Malaysia, tidak terdapat banyak perbincangan tentang landskap fotografi dan tidak ramai juru gambar yang berkemahiran dalam bidang ini. Penyelidikan ini menggunakan analisis kandungan dan analisis foto daripada sumber yang berlainan termasuk monograf, buku, dan jurnal. Esei pendek ini menerangkan pengaruh seni Zen terhadap landskap foto, dan perkembangannya di Barat. la juga menerangkan secara ringkas tentang sejarah landskap fotografi di Malaysia. Selain daripada itu, esei ini tidak berhasrat untuk menerangkan semua teknik dan konsep landskap fotogafi, tetapi saya cuba menghubungkaitkan pengalaman saya dalam landskap fotografi dan mengintegrasi teori fotografi dalam penciptaan landskap foto. Kesimpulan kajian ini menunjukkan ramai landskap jurugambar telah memperkembangkan konsep mereka daripada ideologi dan sumber lain seperti lukisan dan falsafah. Tiada pengaruh Zen atau Gestalt dalam landskap fotografi Lambert dan Thompson ditemui.
\end{abstract}

Kata Kunci: landskap fotografi, lukisan landskap Cina, seni Zen (Chan)m, Gestalt.

\footnotetext{
Senior Lecturer at Faculty of Technology Creative and Warisan, Universiti Malaysia Kelantan
} 


\begin{abstract}
There are not much discussions on landscape photography and also not many photographers in Malaysia specialize in this genre. The research uses content analysis and pictoral analysis from many sources, including monographs, books and journals. This short essay explains the influence of Zen art on landscape photos, and the development of landscape photos in the west. It also briefly explains history of landscape photography in Malaysia. Furthermore, this short essay does not aim to explain all the techniques and concepts of landscape photography, but I try to relate to my own experience in landscape photography and other integrated photograhic theories in making landscape photo. The conclusion of this study indicates that many landscape photographers develop their concepts from the previous ideas and also from other sources such as painting and philosophy. There are no Zen or Gestalt influences on Lambert and Thompson's landscape photographies found.
\end{abstract}

Keywords: landscape photography, Chinese landscape painting, Zen (chan) art, gestalt

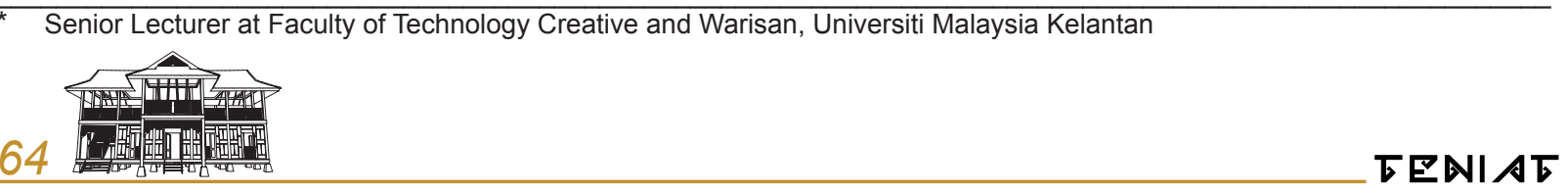




\subsection{Introduction}

It is a big question, why landscape photography is not developed as much as other genres in Malaysia? Although the pioneers of photography in Malaysia had started since British colonial times, Gustav Lambert and J. Thompson had created landscape pictures since the 19th century (Falconer, 1995; Abdullah, 1995; Ahmad, 2015). Landscape photography in the 19th century belonged to the documentary genre. The documentary photography including landscape related to topography survey for colonial purposes. J. Thompson and Lambert had taken landscape photography in Malaysia and Singapore for topography purposes, but not to try to make landscape photography as fine art. The landscape photography was accepted as Landscape photography during Ansel Adams and Group F/64 in 1920s. This paper tries to investigate the influence of Zen (Chan) art and gestalt on landscape photography, and its influences on Lambert and Thompson. As a result, I try to connect the landscape photographic theory with my concept derived from the previous landscape photographers and other artists.

\subsection{Research Method}

The research uses content analysis (Leeuwen \& Jewitt, 2001) in which data are collected from monographs, journals, books and various other sources. The photographs in the research are described by using Barrett's Criticism models. The Barrett Model was used by Chuang (2005) and Zahar (2010).

\subsection{Result}

The earliest landscape painting was found in Catal Höyük. Turkey in ca.6150 BCE. The foreground was interpreted as a town with rectangular houses nearly laid out side by side (Kleiner, 2009). This landscape painting (Figure 1) shows no perspective and it is similar to children's drawings or even modern abstract painting.

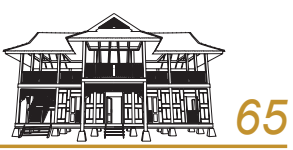




\section{Çatalhöyük, Anatolia - 6150 BCE}

- Landscape with volcano eruption, detail of watercolor copy of a wall painting from Level VII, Çatalhöyúk, Turkey, c. 6150 BCE. WalI painting: Ankara Museum of Anatolian Civilizations, Turkey. Watercolor copy: Private collection

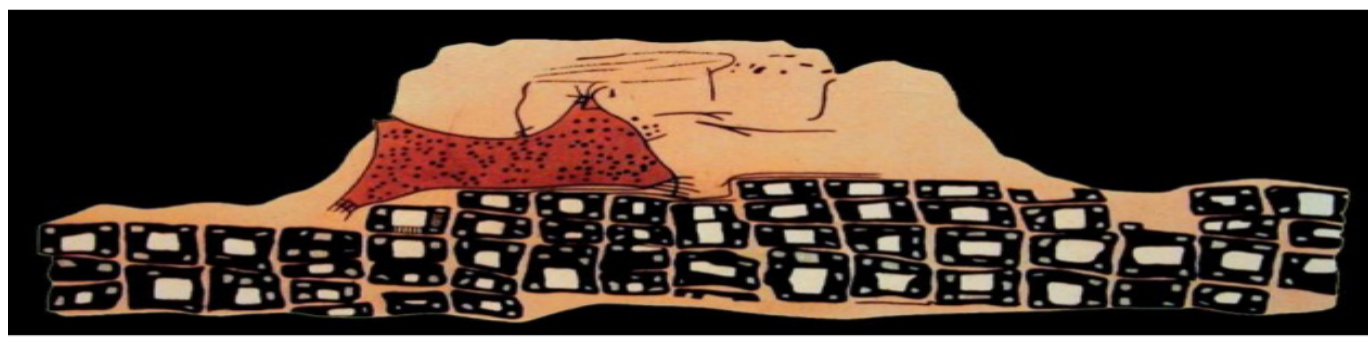

Figure 1: Landscape with volcanic eruption was found in Çatal höyük, Turkey, ca.6150 BCE (Kleiner, 2009)

Beautiful panoramic becomes the inspiration for the artists since thousands years ago. One of the evidence was the Chinese landscape painting which became the rivals of westerners and even started before Han Dynasty (Canhill, 2011). The big landscape painting was interesting because the artist drew in the big canvases. Gradually, the drawing techniques were improved showing diverse dimensions and perspective. The perspective is quite different from the westerners who started to do landscape painting around the 15th century. The western and Chinese landscape painters decreased the size of an object that made the object in the painting appearing farther away. However, the westerners used linear perspective and sometimes they used more than one vanishing point. In contrast, the Chinese painters manipulated the empty spaces, and usually filled with one or two vanishing points and followed the linear perspective. In contrast, the Chinese landscape had also diminished subject matter through distance, but the painters did not use linear perspective. The Chinese painters drew the subject matters such as trees, houses, plants, rocks, but they did not draw the mist, water and left them as blank spaces or with indistinctive brush strokes especially in the later development period of landscape paintings. The empty spaces in Chinese landscape paintings encouraged us to interpret. The westerners used oil painting and drew all subject matters having no spaces without paints. Figure 2 shows that the earliest Chinese landscape painters during the Tang dynasty drew clear outlines of the clouds, rocks and mountains. Therefore, the effects of dimension were not as deep as the later developed landscape paintings. Furthermore, Figure 3 shows the later development of Tang's landscape paintings were more minimal and the painters reduced complete outlines compared to the earliest paintings.

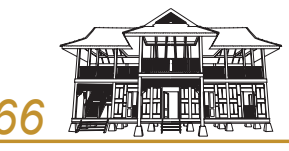

TENIAE 


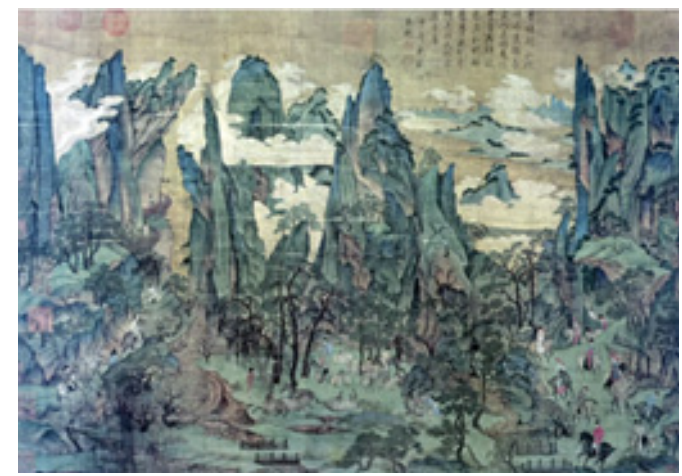

Figure 2: Early Chinese landscape painting in Tang Dynasty (Canhill, 2011)

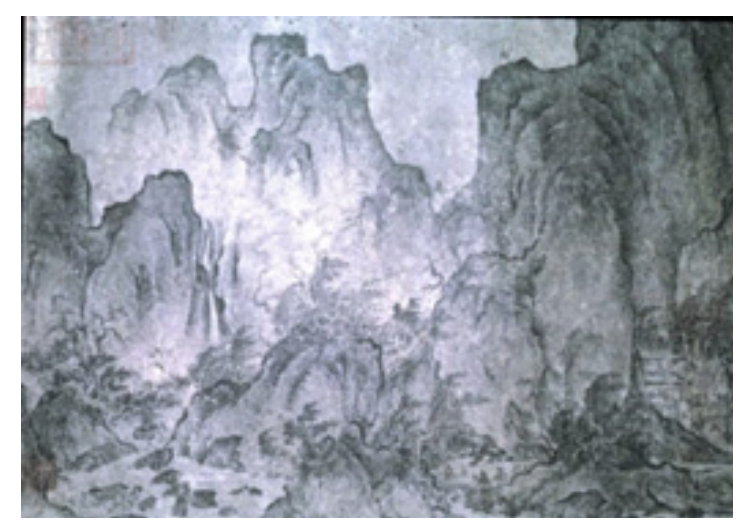

Figure 3: The development of Chinese landscape painting in Song Dynasty (Canhill, 2011)

In the west, landscape painting started around the 15th century and most of the landscape paintings are related to Bible stories, and could be considered as religious art. Leonardo da Vinci drew many elements of landscapes such as water, clouds, plants and also paintings in his famous dairy book. One of his "landscape" can be done by cropping his painting "Annunciation c 1472". The landscape shows the dimension of the paintings. He drew mist to make the mountain lost contrast and fuzzy, so the effect of three dimensions became obvious, and further reduced the size of the mountain. The line of the mountain also became fuzzy and soft. Figure 4 shows Leonardo painted the landscape with oil on wood and the effect was quite different from Chinese landscape in Tang

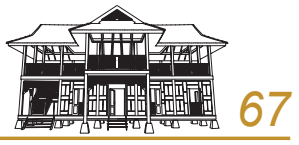


Dynasty. Many Chinese artists used ink and painted on the silk, so the technique was quite different. Leonardo da Vinci drew the landscapes directly on the location. In contrast, many Chinese painters usually walked into the mountains and drew the mountain in the studio (Gombrich, 2006). The Chinese painters drew the landscape from their memories and tried to remember the details of the landscape. If I divided into two shapes, positive and negative shapes, the subject matters such as trees, mountain acted as positive shapes and clouds, skies as negative shapes. Leonardo drew very clear and distinct between positive and negative shapes. On the other hand, the Chinese painters drew the positive and negative in very different ways. The painters did not draw or less paint in the negative shapes. Usually the clouds, river, and lake were not painted and usually the painters just left them empty. Some of the Chinese painters reduced the use of the lines in their subject matters. Leonardo da Vinci used the linear perspective to create a three dimensional effect. On the other hand, Chinese painters made the hill diminished to the depth of the painting. The Chinese painters did not follow the linear perspective, but they drew the mountain smaller and placed it in the back of other hills and also fill the paintings with many empty spaces.

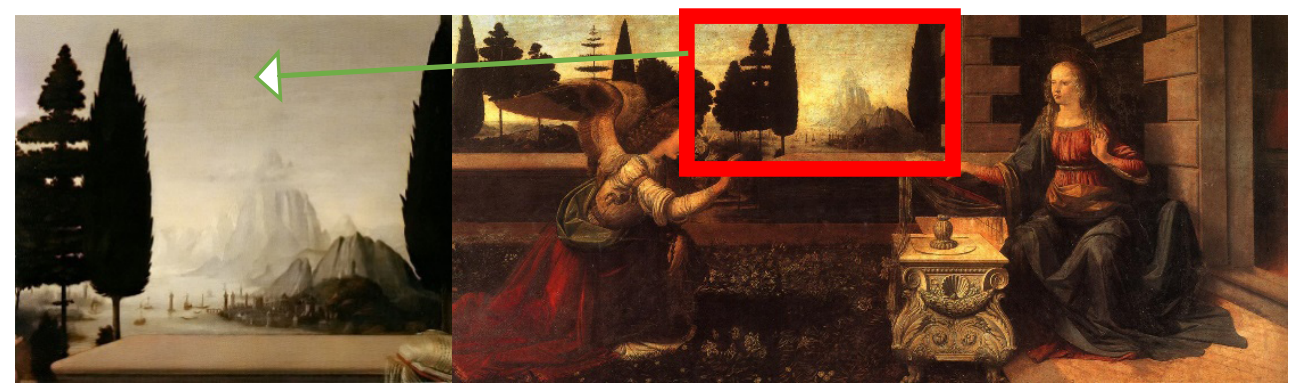

Figure 4: Leonardo da Vinci, Annuciation, c.1472, tempera with oil wood

We can explain the concept of art in western landscape since the $15^{\text {th }}$ century with Heidegger's philosophical theory (Heidegger, 2002) or Derrida's theory of philosophy or other art theory, etc (Derrida, 1987). The process of making Chinese landscape was related to the Buddhism. The activities of creating a landscape painting involved meditation by looking at things, walking and observing the mountain, by starting to paint after the observations and later presenting the paintings in tea ceremony. 


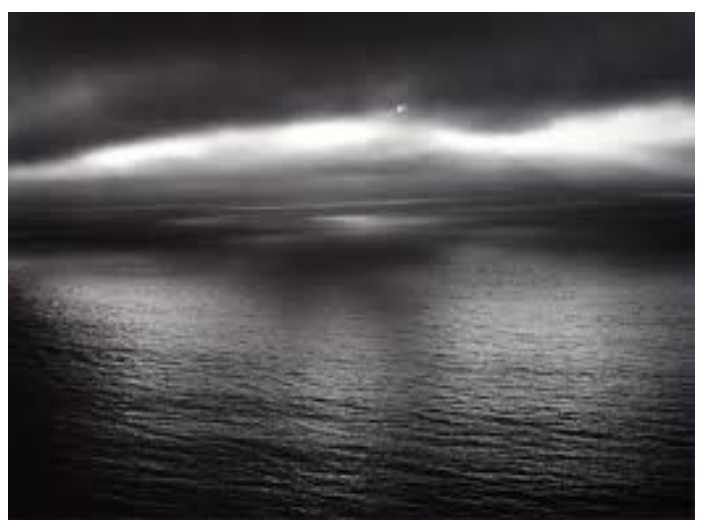

Figure 5: Minor White, Sun Over the Pacific, Devil's Slide, 1947

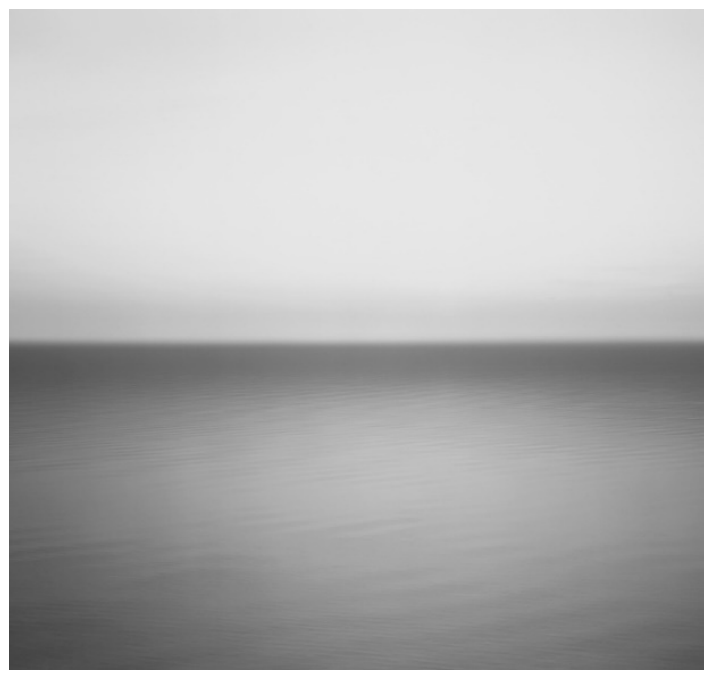

Figure 6: Hiroshi Sugimoto, Carribean Sea, Jamaica 1981

\section{TENIA下}

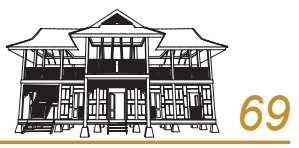


The historical development of landscape photography in Japan was the earliest besides the western countries. The history of Japan started from a tourist photo in the 1870 s, being proposed as a fine art in the Taishö period (1912-1926) and finally served as propaganda to support the colonial expansion into Manchuria during the 20s and 30s (Tran, 2005). Hiroshi Sugimoto and many Japanese photographers showed minimalistic styles in their works, as demonstrated in one of the famous series Seascapes (1980) by Sugimoto. This series were interesting. Sugimoto took the horizon line in the Caribbean sea, Jamaica. He took the landscape, without any foregrounds, but only the horizontal line, sea and sky.

Minor White and Henry Cartier Bresson converted and became Buddhists. Harry Callahan, Minor White and Wyn Bullock did some landscape photography that reflected influences from Zen and gestalt theory. I tried to see negative and positive shapes of Minor White's landscape photo. The photographs still showed quite clear positive and negative shapes compared to Hiroshi Sugimoto as illustrated in Figure 5. It is quite difficult to determine the positive and negative shapes of his series in Carribean Seas. The positive shapes can be negative, and vice versa. Harry Callahan used high contrast black and white prints and removed the gray color. He admired Ansel Adams, although his works did not reflect Ansel Adams's landscape photographic techniques (Zahar, 2015). Ansel Adams adopted complete gray scale in his famous zone systems. Weeds series showed empty space indicating possible influences from Zen concepts, and his arrangement of weeds on the snow mirrored gestalt theory as in Figure 7.

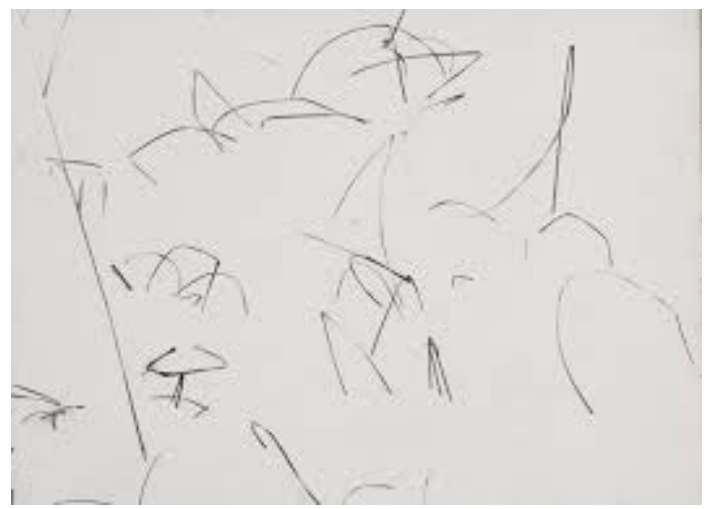

Figure 7: Harry Callahan, Weeds in Snow, Detroit, 1943 
This study leads to several questions. Must Zen Art use ink? Does Zen art have several symbols apart from what have been commonly used by Chinese painters such as monk, nun, and empty space? Do Japanese and Chinese painters or artists naturally produce Zen/Chan art in their works? Does a painter need to practice Zen when creating Zen art? In Eikoh Hoseo's photo - "Kamaitachi" as illustrated in figure 9, informally he used empty space and forms, but it did not mean that his work was placed as Zen Art. Eikoh collaborated with Tatsumi Hijikata, the founder of Ankoku Butoh dance. They documented their improvisational performance in northern Japan. They were inspired by the legend of Kamaitachi, a weasel-like demon who haunted rice fields and slashed people with a sickle. Hosoe photographed Hijikata's spontaneous interactions with the landscape and the people he encountered. Hosoe did not try to create Zen Art, although some of his landscape photos used emptiness and forms. Gregory Levine suggested that Zen Art is likened to a Buddhist "expedient means" that bridges between the Two Truths - absolute and conventional, transcendent and immanent, emptiness and form. Levine did not support Oscal Wilde's comment about Japan that whole of Zen Art is pure invention or, Roland Barthes' opinion that Zen art is an empty sign (Levine, 2007). Why does the emptiness in the paintings become important? There was possible relation to the Chan (Zen in Japan) philosophy that we need to be emptied to learn something new and also we need to empty our self-ego to achieve better life or to be enlightened. There were two schools of Chan under Song emperors (960-1279), the "Northern" and "Southern" School of Chan. The Northern School believed that enlightenment can be achieved only after long meditations. However, the southern school held the belief that one attains enlightenment through sudden and spontaneity (Kleiner, 2009). In order to create Zen Art, artists did not necessary need to change religion or belief, or even live as monks or nuns. Spirituality was the big concern for Wassily Kandinsky. He thought that western art lost its soul, and religious art is presented in all true arts (Kandinsky, 2008). Zen art is a religious art and we can still produce a good quality of art, although we are not Buddhist followers. Van Gogh studied Japanese woodblock prints and copied the same forms, but he used oil paints and his famous strokes (Mancoff, 1999). Van Gogh developed his techniques and some of his famous works was influenced by Japanese art especially the sunflower series.

The Zen concept in art can be applied as modernist and post-modernist concept or future concept. The person who learns Zen art could be from very different cultures and backgrounds of the Chinese, Japanese and Korean. The artist needs to integrate the values and Zen spirit into the works of art. Monks meditate with word or things in nature, on water, for instance, and what we can learn from it; or on mountain to know how strong and lordly they are (Gombrich, 2006). It is also possible to make the painting as a tool to measure their meditative achievement since Tang dynasty (618-907). The process of making Chan (in China) or Zen paintings, which was considered as religious paintings, were different from this day, especially if we can from totally different cultures and use different forms of media. Imitating Chinese landscape paintings is not easy with straight photography with or without digital manipulation. The camera inclines to make linear perspective and show clear vanishing points. Wyn Bullock and Hiroshi Sugimoto choose seascapes to represent Zen Art and do not choose a 
mountainous area which the Chinese landscape painter normally draw.

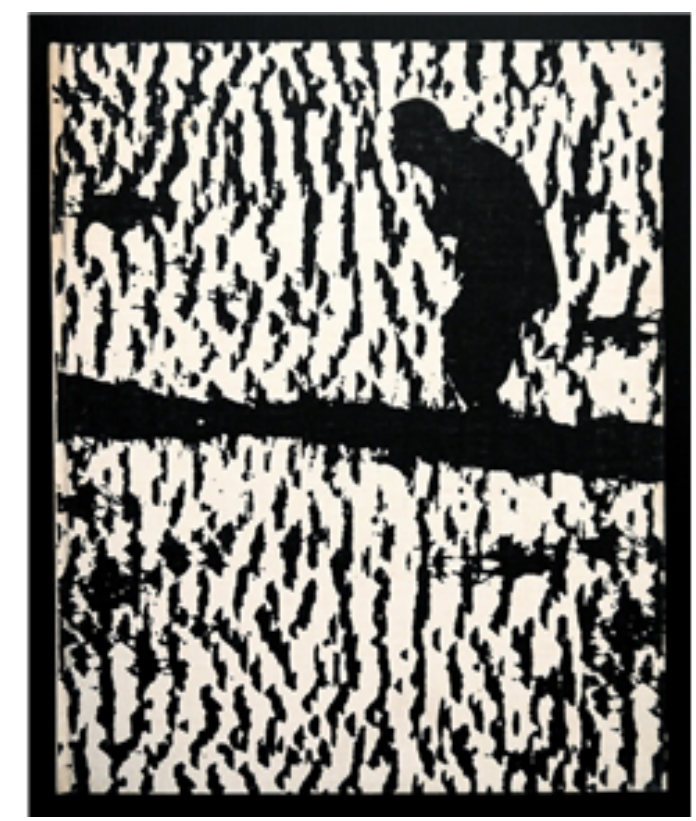

Figure 8: Eikoh Hosoe, Kamaitachi, 1969

\subsection{Topographical Photography in Malaysia and Indonesia}

After the invention of the photography, topographic photography becomes a scientific instrument to depict monuments from other cultures and civilizations (travel photography) and their significance for sciences such as anthropology, ethnography and archaeology (Skoufias, 2006). Topographic photography is used for science and archive, and not for fine art. The topographical functions, both domestic and expeditionary, are to confirm identities at home and explore new virgin territories with expeditionary forces such as US Mid-West landscape photography with photographers such as Timothy O'Sullivan (Sandler, 2002). Timothy O'Sullivan is another specially gifted survey photographer. O'Sullivan and the other survey photographers encounter difficulties in capturing their images when they travel to places dominated by dangerous mountain and deep valleys. They carry a big camera and have to develop each negatives on the spot (Sandler, 2002). This expeditionary documentary photography has a narrative function as it records the'story' of imperialist/colonial enterprises (Skoufias, 2006).

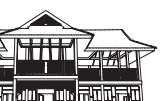


The survey photo was conducted by Gustav Lambert, JJ Thompson, Woodbury and Page in Indonesia and Malaysia as illustrated in Figure 10 and Figure 11. The Vereenigde Oostindische Compagnie (VOC) and British colonial also produced topographic documentary. Two photographers, Gustav Lambert and John Thompson, were not landscape photographers, but some of their works showed landscape photos around Malaysia. John Thompson (1837-1921) wrote about photography in his illustration of China and its people (Merrillees, 2000). Gustav Lambert stayed and opened a photo studio in Singapore. He took pictures around South East Asia (Falconer, 1995). The use of his landscapes photos were for topographical purposes, and not for the purposes of fine art. The landscape photos during this time already showed good techniques of photo, with sharp focuses, and good compositions. The photos used rules of third, diagonal, and perspectives.
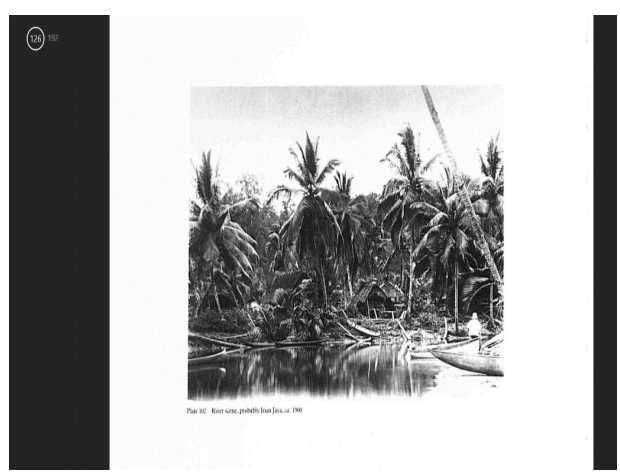

Figure 9: Lambert, River Scene, probably Iran Jaya, ca 1900 


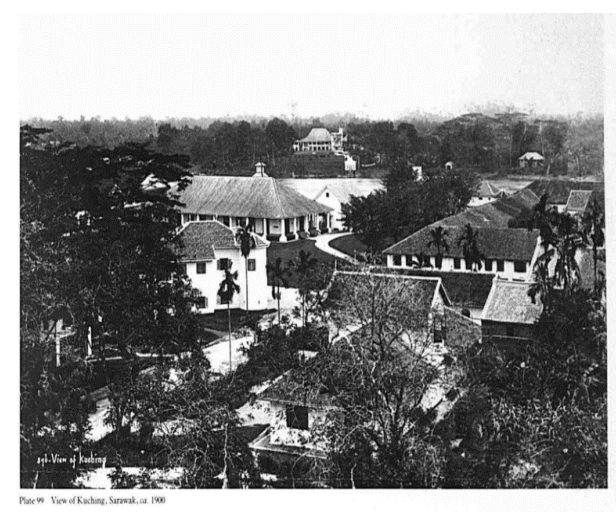

Figure 10: Lambert, view of Kucing, Serawak. ca 1900

As illustrated in Figure 11, Woodbury travelled to Java where He founded a photographic firm with James Page and they opened a photo studio in Batavia (now Jakarta) and recorded some important places and old city of Jakarta (Kota Tua) (Merrillees, 2000). In 1863, Woodbury and Page offered a list of sixteen topographical photographs of the city for sales in albumen format. These images were considered the first of their sort from Batavia, which was originally established in 1619 as a colonial supply station for the VOC or the Dutch East Indies Trading Company (Fahey, 2007).

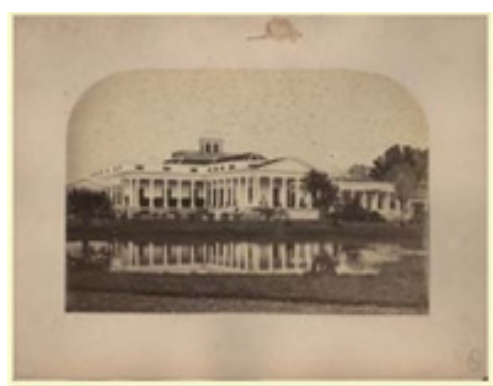

Figure 11: Woodbury, Back View of Gov. Genl's Palace at Butenzorg, Java

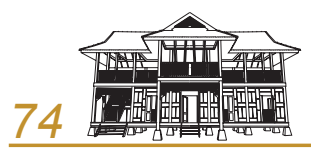


Nearly all Landscape photographs during Dutch and British colonies were documentary photographs. Those photos were made not to make fine art photography. I am not trying to discuss Landscape photos during pictorial movement. Those photographers who imitated painters by doing a lot of retouched, fuzzy and unsharp pictures, used soft focus and some photographers did hand coloring. One famous photographer, Edward Weston, used to follow this style and changed his style to straight photography. He called the pictorial photograph as "pseudo painting" (Barrett, 2006). Edward Weston and Ansel Adamss created Group f/64 and became one of the famous groups ever known in photography, especially Ansel Adams (Zahar, 2010). Why is Ansel Adams so popular? One of the reasons is that his photo techniques in printing black and white through Zone Systems are very outstanding (Adams, 1995). Ansel Adams and his Group F/64 produced straight photograph which technically was not so different from the techniques used by Kasian Chepas, Lambert, and John Thompson. However, Ansel Adams introduced a new approach in observing the landscape. He observed the places and he took landscape in Yosemite National Park for nearly 50 years as illustrated in Figure 12.

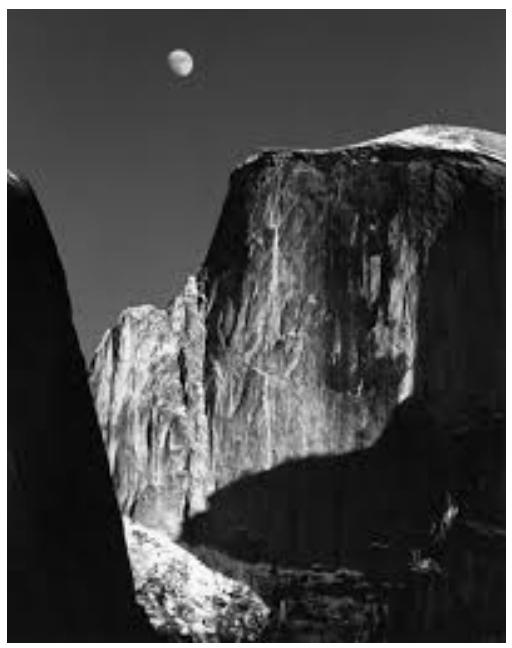

Figure 12: Ansel Adams, Moon and Half Dome, Yosemite National Park, 1960

The Chinese landscape painting since Tang Dynasty, western landscape painting from 15th century to John Constable, Ansel Adams and his Group F/64( (Zahar, 2002) can be considered as realism. The process of creating the art products is different. Although the Chinese paintings are not as realistic as Western paintings, but their artworks showed the world of realisim. E.H. Gombrich and James Canhill had never thought that the Chinese painting are not realistic (Canhill, 2011). Photography is more realistic in their representations compared to Chinese paintings and western landscape paintings.

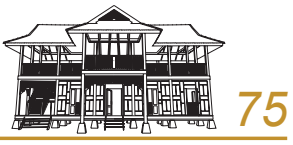


Harry Callahan admired Ansel Adams, and quited from his job in automotive industries as illustrated in Figure 13. He took pictures from his surroundings and he knew very well. His wife and his daughter sometimes become his model. He took also landscape with many photo techniques. Harry Callahan was not purist as AnselAdams. He changed size of camera, print with many techniques and composition. Some of Harry Callahan's works was influenced by Zen Art in particular when he played with empty spaces.

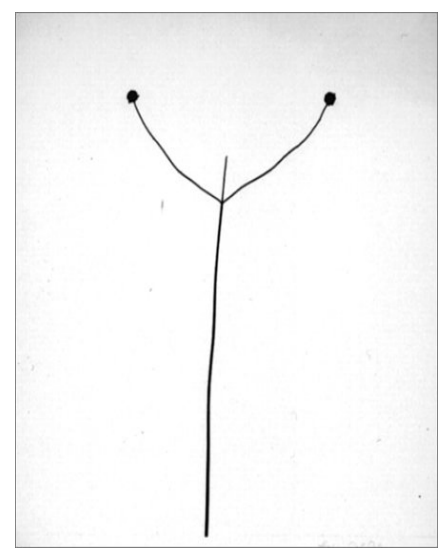

Figure 13: Harry Callahan, Weeds against the sky, 1948

Ernst Haas pioneered in color photography and took also landscape photographs. He used low ISO, SLR $35 \mathrm{~mm}$ camera and various lenses including micro lens (Zahar, 2015). His landscape was influenced by the impressionists. He liked to take pictures in the late afternoon or morning, after the rain, so he liked to take silhouette and used slow speed and low ISO. His color photographs were saturated. Other things, he broke the rules of photography. If compared with Ansel Adams, Ernst Haas broke the rules of photograph. Figure 14 shows that, slow speed without a tripod and he was also well known as the photographer who developed panning techniques. The impression of his photos became similar to those by impressionist painters. 


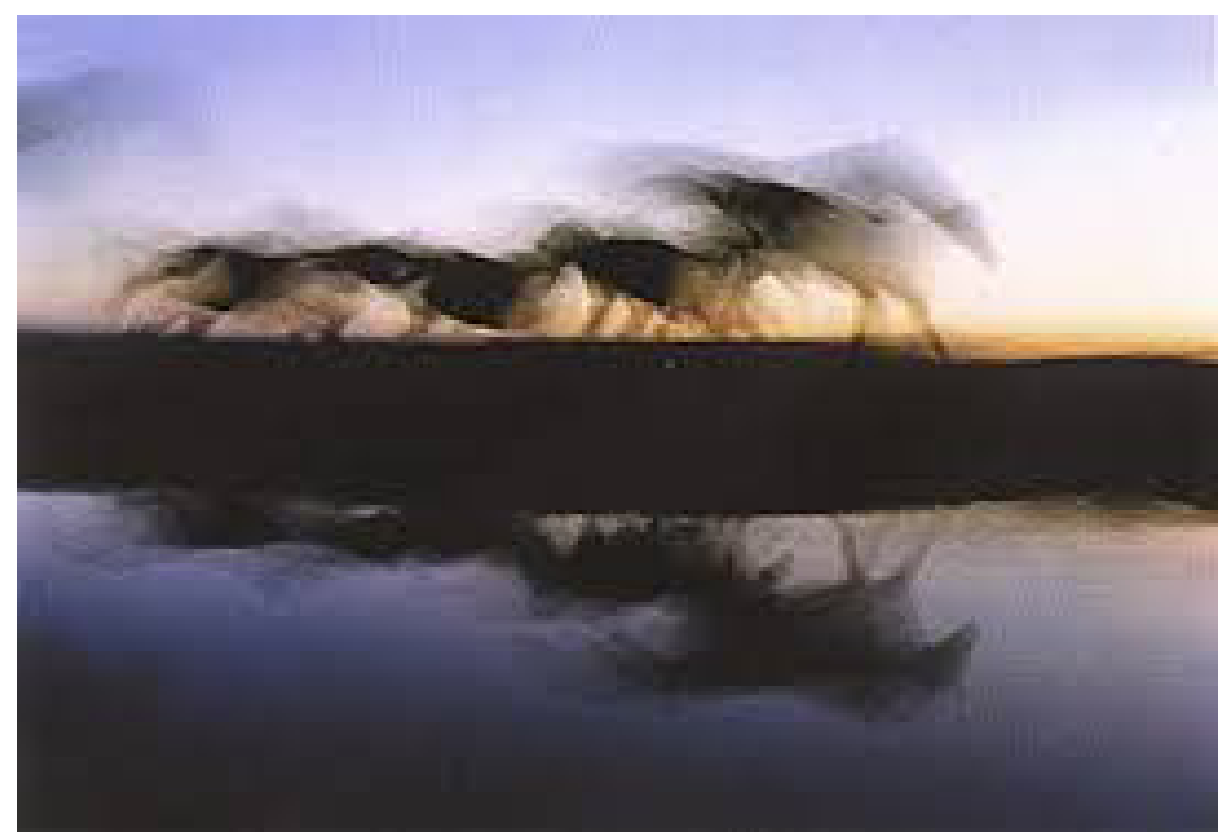

Figure 14: Ernst Haas, Wild Horses, Nevada, 1957. 


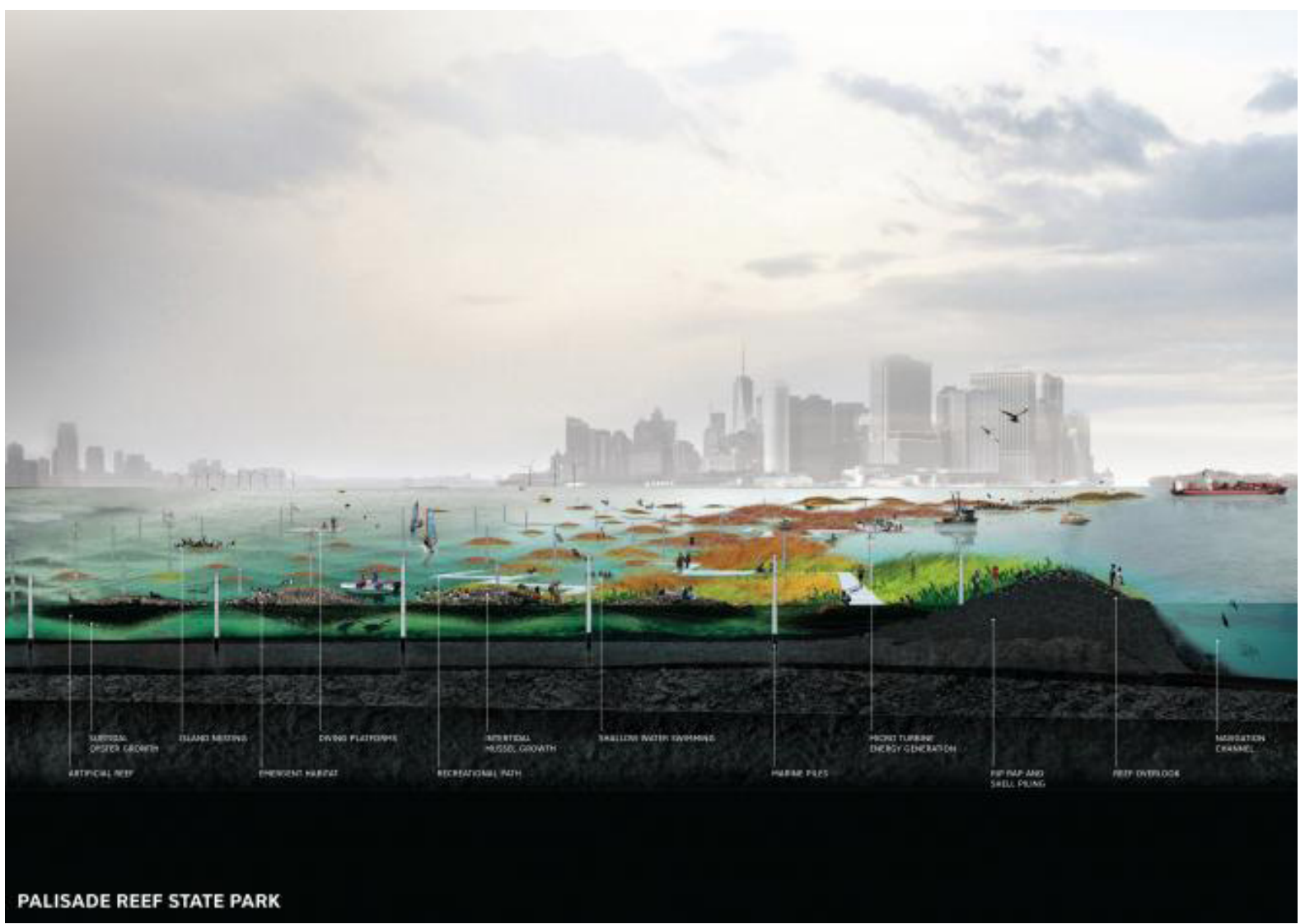

Figure 15: Richard Misrach, Petrochemical America, 2012

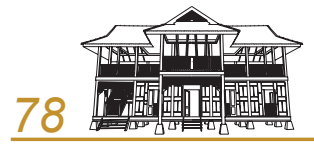

БENIA下 
Heidegger pointed out that art not only showed beauty and aesthetic, the truth of art can be important. The beauty of the art is more related to the aesthetic, in contrast with the truth of art is related to logic (Heidegger, 2002). Landscape photo during Ansel Adams emphasized on beauty and aesthetic. They were less concerned about environmental destructions such as pollution, deforestation, etc. The truth of the landscape photo during postmodern era was related not only to beauty but also to the destructions of the landscape. In fall 2012, in collaboration with landscape architect Kate Orff, Misrach launched a major book and an exhibition entitled Petrochemical America, which addressed the health and environmental issues associated with our dependency on oil.

I tried to implement Ernst Haas' concepts, Harry Callhan's methods of taking pictures, and the impressionist concepts of creating pictures. I tried to symbolize the deforestation with burning the leaves as illustrated in Figure 16 and Figure 17.

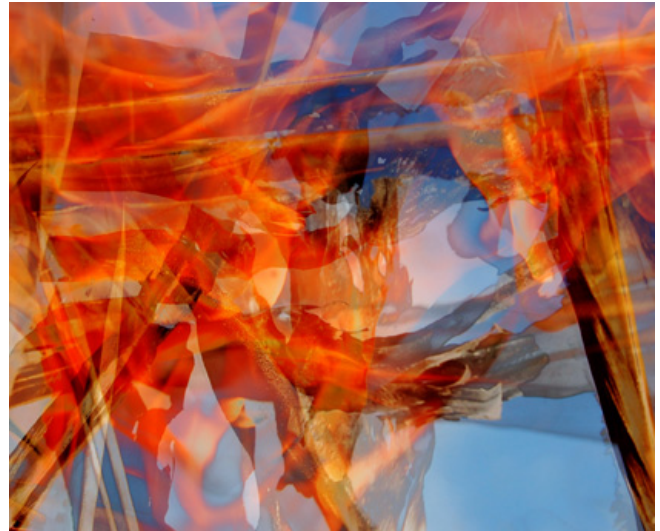

Figure 16: Deforestation \#2, Kota Bharu, 2013

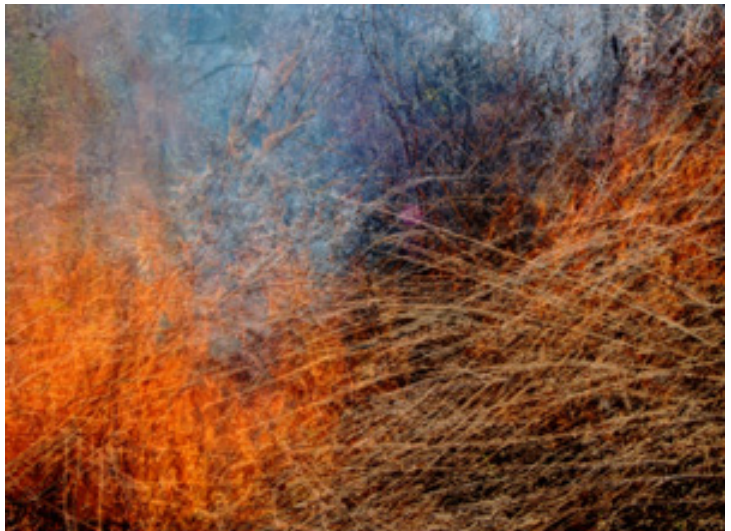

Figure 17: Iwan Zahar, Deforestation, Kota Bharu

In my other project, I took pictures of rubbish around Pantai Sabak for nearly one year. I tried to choose the unexpected subjects with seascape as the background as shown in Figure 18 and Figure 19. The bottles came from many shapes and functions. Some bottles were alcohol bottles.

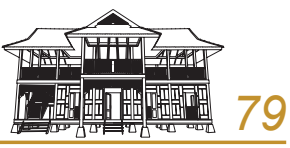




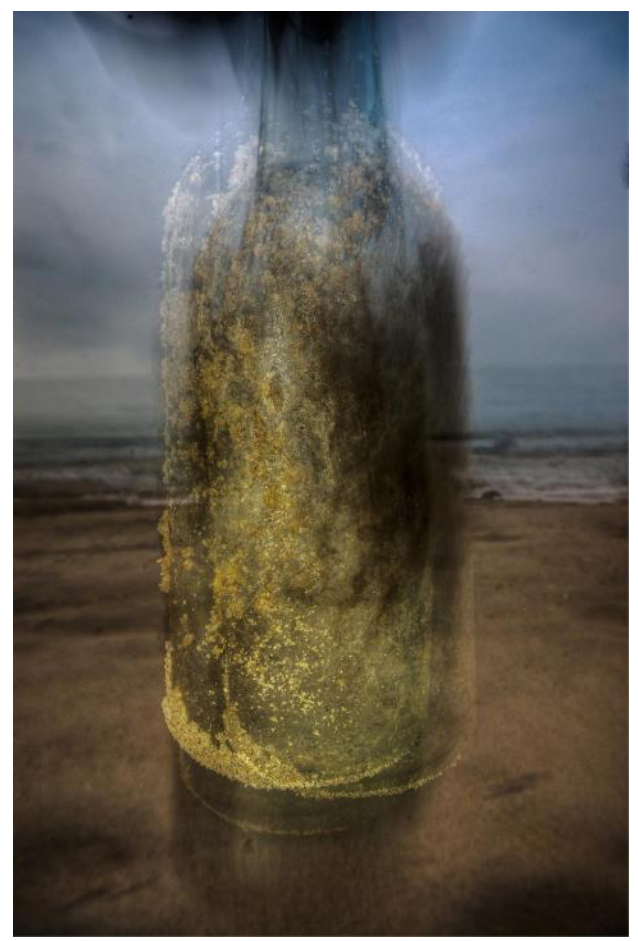

Figure 19: Iwan Zahar, Rubbish Bottle 32, 2014

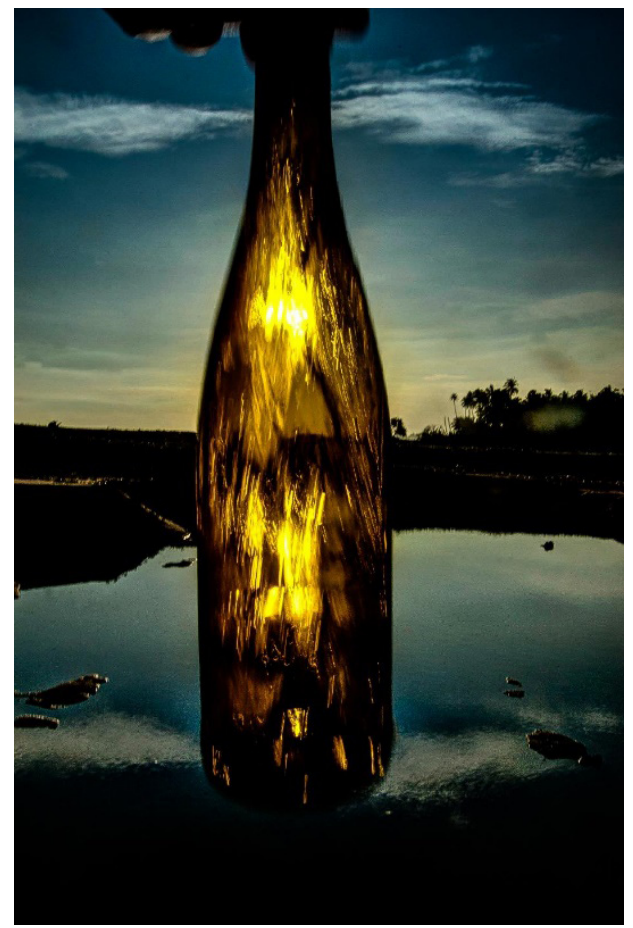

Figure 20: Iwan Zahar, Rubbish Bottle, 2014

In order to develop landscape photos, we need to develop the concept from various sources and enrich our photo styles through photographic experiments. 


\subsection{Conclusion}

The Zen concepts influence many western and Japanese photographers. The westerners try to learn and apply Zen concepts in their works. It is possible that the Japanese photographers do not deliberately apply Zen concepts but they have absorbed it thro ugh their own culture. Lambert, Thompson and other photographers embraced landscape for topographical purposes in colonial times. Most of their landscape pictures were of professional standards but not very special. They did not intend to make a landscape photography as fine art like what the Group F/64 did in the 1920s. Further research should be conducted in Malaysian Landscape photographs. 


\section{Rujukan}

Abdullah, I. (1995). Documentary Photography: A Study of nineteenth century documentary photography with special reference to West Malaysian historical photographs 1874-191. Goldsmiths College, University of London.

Adams, A. (1995). The Negatives. Ansel Adam Publisher.

Ahmad, W. L. (2015). Kajian Analisis Kandungan Foto Hitam Putih Masyarakat Melayu Abad ke 19 Karya Gustav Richard Lambert. Kota Bharu: Universiti Malaysia Kelantan. Retrieved from http://umkeprints.umk. edu.my/5004/ 1/LOKMAN\%20IR.pdf

Barrett, T. (2006). Criticizing Photographs, An Introduction to Understanding Images (4 ed.). Boston: Mc Graw Hill.

Barthes, R. (1977). Image-Music-Text. (S. Heath, Trans.) New York: Hill and Wang.

Canhill, J. (2011). Introduction and Pre-Han Pictorial Art. Lecturer in Youtube. Retrieved 11 10, 2015, from https://www.youtube.com/watch?v=KJ4S-jCh4iE\&list=PLdwCuEoZ_6I6ZmRhv6QPsxNKKW1w75dhl

Chuang, C. C. (2005). A Descriptive Case Study of Impact of Professor's Teaching Strategies on Taiwanese College Students' Photographic Image Interpretation. Pennsylvania: Pennsylvania State University.

Derrida, J. (1987). The Truth in Painting. (G. B. Leod, Trans.) Chicago: Univerisity of Chicago Press.

Fahey, M. (2007). Walter B Woodbury Photograph Collections 1865-1866.

Falconer, J. (1995). A Vision of the Past. Singapore: Times Edition.

G, M. (1998). Landscape Photography, Photospeak: a guide to the ideas, movements, and techniques of photography 1839 to present. Abbeville Press.

Gombrich, E. (2006). The Story of Art. London: Phaidon Press Limited.

Haas, E. (1976). The Creation. Penguin Books.

Heidegger, M. (2002). Off the Beaten Track. (K. Haynes, \& J. Young, Eds.) Cambridge: Cambridge University Press. 
Kandinsky, W. (2008). Concerning the Spiritual in Art. Portland: The Floating Press.

Kleiner, F. S. (2009). Gardner's Art through the Ages: A Global History. Boston, MA: Thomson Wadsworth. Leeuwen, T. V., \& Jewitt, C. (2001). The Handbook of Viusal Analysis. SAGE Publications.

Levine, G., \& Lippit, Y. (2007). Awakenings: Zen Figure Painting in Medieval Japan. New York: Japan Society.

Mancoff, D. (1999). Van Gogh Fields and Flowers. California: Chronicle Books.

Merrillees, S. (2000). Batavia in Nineteenth Century Photographs. Singapore: Archipelago Press.

Rabate, J.-M. (1997). Writing Images after Roland Barthes. In c. shloss, \& J.-M. Rabaté (Ed.), Narrative Liaisson Roland Barthes and The Danger of the Photo Essay (pp. 99-108). University of Pennsylvania Press.

Sandler, M. W. (2002). Photography An Illustrated History. Oxford: Oxford University Press Inc.

Skoufias, E. (2006). Narratives in Landscape Photography: The Narrative Potential of Transitional Landscapes. University of Westminster.

Tran, J. L. (2005). From Yokohama to Manchuria: a photography-based investigation of nostalgia in the construction of Japanese landscape. London: University of the Arts.

Zahar, I. (2002). Catatan Fotografer: Kiat Jitu Menembus New York. Jakarta: Creative Media.

Zahar, I.,(2010). Pengembangan Model Pembelajaran Berbasis Masalah untuk Interpretasi Foto. Jakarta: Universitas Negri Jakarta.

Zahar, I. (2015). Photo Exemplar Classification: The Integration of Photographic Technique. In O. H. Hassan, S. Z. Abidin, R. Legino, R. Anwar, \& M. F. Kamaruzaman (Eds.), International Colloqium of Art and Design Education Research (i-CADER 2014) (1 ed., pp. 161-172). Singapore: Springer-Verlag. doi:10.1007/978-981-287-332-3_18 
